which a lecturer can make on the assi- been suggested, we understand, in several duity of a pupil, when the share of duty of the schools, that an faggregate meetwhich that lecturer undertakes to dis- ing of the medical students of the metrow charge for the pupil's benefit does not re- polis should be held in a central part of quire of him to be in the lecture-room the town. Should such a measure be more than three or four hours in each deemed desirable, a committee of senior week? And yet, with a full knowledge students should be formed, in order to that the intercourse between lecturer and arrange, with appropriate care and delistudent is thus restricted, the teacher is beration, all those proceedings which are called on to report on the extent of his necessarily preliminary to the accomplish. pupil's assiduity, to which may be added ment of a great public object.

all the "et ceteras" which malice, falsehood, and envy, can invent. As it is not possible for the teachers in the largest of our schools, according to their present arrangenents, to become acquainted with the habits of the students, it is unjust, nay, absolutely infamous, that those lecturers should be called upon to make remarks on the character of the pupils on the hearsay evidence of a set of hired underlings. If the existing system of medical edncation brought the students and their teachers more frequently into each other's presence,-if the number of theatre-lectures were less, and the number of private admonitions were greater, -if there were resident medical officers in our hospitals who were ready to furnish during several hours of the day the benefits of clinical instruction,-then the testimonials relative to absence and attendance which cuuld be furnished by officers so circumstanced, might be received as valuable documents; but cren such men ought not to be permitted to deal in "et ceteras," and no institution of character or infuence would descend to ask for information under a title which is rendered disgusting by its worse than equivocal signification.

Ix another part of our Journal will be found a report of some proccedings which have taken place at the London University, in consequence of the issuing of the epy regulations of the College. It has

THE clearing power of the press was very conspicuous in the operating theatre of Guy's Hospital on Tuesãay last, when Mr. B. Cooper removed a penis from one. patient; and Mr. CALLAwAX operated on another. During the performance of these operations, the surgeons, the patients, and two dressers, were the only persons present in the area of the theatre, the floor of which used to be considered as remarkably clear when a dozen spectators were standing there. We have often seen between thirty and forty persons surrounding the patient on the floor of the theatre during an operation.

THE ANATOMY ACT.

FIRST LETTER TROM PROLESSOR QUAIN, LOXDOX UNIVERSITY.

To the Editor of THE LANCET.

SIR,--A statement appeared in the Morning Post newspaper of Wednesday last, purporting to set forth a correct view of the working of the Anatomy Act. The writer, who in this instance comes forward as a correspondent or voluntecr contributor to the Post, appears to be a lecturer on anatomy in one of the schools, and is evidently under the influcnce of much morbid feeling, which he evinces in almost every paragraph by keeping up a continued fire of abuse and inputation against one of the Secretaries in the Home Office, the framer of the Bill, and the Inspector who has been appointed to carry its provisions into effect. The Inspector is described as being a "young man," 
who, from circumstances, is ill-qualified to 4 carry into effect the provisions of the bill,"-and as being "closely allied with persons whose avowed object is to level all to grades and ranks in the profession," and, by way of completing the catalogue of his offences, and concentrating into one point the grounds of his unfitness for his oftice, we are told, "that he is known to be intimately connected with Mr. Warburton."

Mr. Warburton is stated to be a person " whose hatred of all establishments is notorious, and whose interests make him doubly zealous to sacrifice all the existing schools to the London Cniversity." Mr. Phillips, the Under-Secretary of State, is also brought forward, as being a person "who has avowed his determination to depress the larger schools and to afford every possible facility to the less distinguished and less usiful establishinents," and our sapient anatomist and letterwriter avers that he has heard what he avows "from good authority."

I give the words just as they are written. I quote these passages to enable your readers and the puhlic to form an estimate of the spirit and feelings of the individual who affects a solicitude to rectify abuse and oppose mal-administration. I know nothing personally of the anthor of this letter, but I know quite enough of his party and of their tactics to be able to form an estimate of their views, and of the measures which they contemplate, as well as the machinery by which they are to be carried into effect. The letter deserves attention, not only from the style in which it is written and the spirit in which it is conceived, but still more because it carries upon the face of it evidence of its being intended as a justification of the opinions and views of a few teachers of anatomy, who wish to ger rid of a plan of proceeding under the Anatomy Act which they themselves advised and concerted soon after its coming into operation, and which they laid before the Home Secretary, in order to secure his co-operation in carrying it into effect.

At a meeting of the teachers of anatomy held some time after the passing of the Act referred to, it was unanimously resolved, that the bodies obtained for the purpose of anatomical examination should be distributed amongst the different schools in London equitably, the number assigned to each heing proportioned to that of its students. Mr. Stauley presided on this occasion, and with a vicw to carry this resolution, the Inspector of Anatomy was requested $t$ ) direct the distribution, with which request he complied. At a subsequent meeting Mr. Stanley and Mr. Mayo chowed a disposition to depart from the agreement thus entered into, and this disposition they have continued to manifest at every step of their proceedings down to the present time.

Having observed this from time to time, I was not surprised at witnessing any effort which might be made to thwart the measure of equitable distribution, and upset any plan of proceeding which might be devised to carry it into effect ; and the publication of the letter iu the Post renders it obvious that decided steps are about to be taken to overthrow it altogether. I will not be so unjust to Mr. Stanley or Mr. Mayo as to insinuate that either of them is the anthor of the letter. I do not think that they had anything to do with it; and $I$ am willing to believe that there is not more than one individual amongst the teachers, who would put forward such statements as it contains.

Why, it may be askcd, is the Morning Post selected as the mediun of an address to the public on the management of anatomical schools, and the plans adopted for the supply of bodies for dissection? Is it that the readers of that paper take an interest in these matters, or know any thing about them ? Is that journal, however respectable it may be, the instrument which any person really disposed to correct abuses in medical concerns would choose in order to bring to bear upon them any efficient demonstrations of public opinion? On these points the reader will form his own opinion.

I pass to a consideration of the " evils" and the remedy proposed for them. The first is that " since the bill has passed, the schools have not been adequately supplied." The second, that " some schools are favoured by the Inspector." The latter would be a very serious evil if true; it is one which should not be permitted to exist for a single hour. Its truth or falsehood may be readily ascertained, and yet those with whom the charge originated, and who have industriously circulated it, are very tardy in supplying the means of removing all doubts conccrning it. The teachers of anatomy have been required to forward to the Home Officc returns of the numbers of their pupils. Returns have been made by all the schools $w$ ith a few exceptions. When these partics have sent in their lists, it will be very easy for any individual who is so minded, to establish the charges against the Inspector if they are true.

When the complaint against the Inspector shall have been investigated, I suspect it will be founl to be aboutjust as true and as tenable as the imputations cast upon $\mathbf{M r}$. Warburton that he is filled with "interested prejudices," and on Mr. Phillips that he makes " mischievous and absurd regula- 
tions," and leads the Chief Secretary away by "misrepresentations." I would not do the writer of this letter the injustice,-I would not detract from his understanding and acuteness so much as, to believe that he is convinced of the truth of either of these imputations. No, he has an object to attain, and is not over scrupulous in the means which he resorts to for its accomplisbment. His object is to procure the adoption of his own favourite " remedy" for the defective supply of bodies to the schools. His remedy is to "let the lecturers and teachers exert themselves amongst the parishes," and " have a motive for their exertions ;" and he promises to double the supply by such exertions. So anxious is the writer to commence operations that he intreats Lord Duncannon not to be "led away by the misrepresentations of Mr. Phillips," "the interested prejudices of Mr. Warburton, or the false statements of the Inspector:" thereby implying that he himself is the only adviser whose counsel should be listened to. If this gentleman, or those with whom he acts, meant fairly, I for one would not object to his "remedy."

But it is notorious that these partics confidently expect that they can accomplish the destruction of the smaller schools, and thereby increase the number of their own pupils, if they can induce the authorities in the Home Office to adopt the course which they point out, and let them have a motive (the strongest motive which can impel such minds), that of personal interest, for " exerting themselves among the parishes." In this expectation they are countenanced by some men of high rank in the medical profession, who think that there are too many schools, and that their number ought to be diminished. Even if the number of the schools were an evil, or if any of them be in bad odour with the "ruling powers," which $I$ hope is not the case, is it to be tolerated in the present times, that a few teachers, backed by some leading surgeons connected with the hospitals, should league themselves together to remove what they are pleased to consider an evil, by construing in their own way, and wresting to their own purposes, the provisions of an Act of Parliament?

Though the letter in the Post is the act of an individual, the sentiments it expresses and the views is puts forth are entertained by a considerable party. Its ingenious author appears to have fiung it as a missile at the Secretaries in the Home Office, in order to deter or disgust them from further interference in such concerns, hoping that he and his party may thenceforth be enabled to proceed unmolested to the attainment of their longwished-for object-that of underminieg certain schools, and depriving them of the means of carrying on the business of instruction; for they calculate on outstrip. ping all rivalry in that sort of competition in which they are so anxious to engage, a competition in body-snatching among the parishes. I shall enable you to understand the tactics which will be played off, and the mancurres which will be resorted to, if such a competition again commences, by briefly stating what has been done by the same parties within the last year or two.

At the commencement of the session $1832-33$, the teachers of anatomy appeared for a while to be a united body. A feeling seemed to exist amongst them that they were to endeavour to induce as many parishes as possible to sanction the principle of the Bill, and that they should act each in his own district for the general good. Special resolutions, it is true, had been passed in several places in favour of particular schools, but this did not seem to be a matter of much consequence, as from the aspect which things then wore, it seemed probable that all these sources would in a short time form a common fund, out of which the schools would be supplied. This expectation was soon found to be altogether delusive, for an intimation reached us, now from one quarter, now from another, that inducements were held out to the directors in different parishes and public institutions, sufficiently cogent to make them confine the supplies of bodies altogether some of the hospital schools. In some cases, the directors were reminded that their sick poor had been from time to time received into the hospital, and it was asked, ought they not in fairness to send all the unclaimed dead bodies to the school of anatomy in that hospital? In others where no previous connexion had existed with the hos. pital, an offer was made to receive such of their sick as may require surgical aid, if they would pass a vote in favour of the school. In short, this consideration was put before them in a great variety of ways; and no one could show more ability than Mr. Stanley in putting forward such inducements as these. He showed the skill of a first-rate artist in varying them, I had almost said ad infinitum. Before I knew his eminent capability in this line, I made an arrangement with $\mathrm{Mr}$. Stanley to accompany him to a parish board, in order to state to the members of it (most of whom were favourable to the principle of the Bili), that the teachers were acting in concert, and that it made no difference whether they passed a vote in favour of 
one, two, or more schools. However, a day or two before the expected meeting of the Board, I learned that the hospital interest had been brought to bear with such effect in a particular parish, that a special vote in favour of the school in st. Bartholomeu's Hospital would be passed on the ground that the sick poor were occasionally received into that institution. Having learned this from one of the churchwardens, I resolved not to interfere any further, in which I was certainly wrong, for the directors, after hearing a statement from Mr. Grainger, resolved not to pass an exclusive vote, and so they included Mr. Grainger's name with that of Mr. Stanley. Seeing the turn events were taking, I did not consider myself called upon to keep the appointment above mentioned with Mr. Stanley, and felt that it became necessary to walk very warily, henceforward, whilst moving in the same path with that gentleman. Shortly after this occurrence, a demonstration of the hospital infuence was made, which showed the extent to which it would be pressed whenever an occasion offered. The governors of a charitable institution directed the unclaimed bodies to be given up to three schools which were named in their resolution. This however was not long in operation, for at a subsequent meeting it was rescinded, and a vote passed in favour of the school in St. Bartholomew's Hospital, the ground of the new decision being that such of the patients as required surgical aid were received into the hospital, and that therefore as a return, the unclaimed dead ought to go to the school. I understood at the time of this occurrence, that an eminent surgeon attencled the meeting, and urged the plea here stated. It is but fair to $\mathrm{Mr}$. Stanley to add, that he did not interfere in this particular instance.

It may be supposed that this sort of influence was brought to bear only in cases of competition with private schools, and that strict forbearance was exercised with regard to those connected with the hospitals. Such however has not been the case. The men of St. Bartholomew's are far too impartial to make any such petty distinctions, and appear to consider it quite as legitimate to trip up an hospital school as any other. A vote was passed by the governors of orie of the prisons in favour of the school in \$t. Thumas's IJusyi$t a l$, but in a little time it was cancelled, and St. Bartholomer'"s was adopted in preference. It is due to Mr. Stanley to say, that he disclaimed the honour of this achievement, and awarted it to a well-known city knight, who made the move without consulting him.
Now pray, good Mr. Editor, step with me for a little into the Borough, that we may see how the campangn went on in that quarter. The Borough King won more victories in a few short months than any other potentate whom we know or have read of. He rode triumphant at every point, carrying all hefore him. With one hand he smote Grainger, with the other demolished St. Thomas. By Jove "Twas greatly done." You will say, doubtless, what did ho do? Attend, and you shall hear. I transcribe in sober seriousness the following short passages from a statement which has been sent to me by a perscn who vouclies for its accuracy. In the parish of $\longrightarrow$ " the officers passed a resolution to send all unclaimed bolies to the three schools in the Borough, the number assigned to them respectively being proportioned to that of the pupils attending each school.

"Mr. Harrison, after this resolution was passed, offered to receive the sick. paupers of the parish into the hospital, without the usual weekly payment, on condition that all the borlics available under the Anatomy Act should be sent to the sehool in Guy's Hospital." My informart does not say whether the offer was accented. A similar offer was made in a neighbouring parish, and the officers of Guy"s" moreover "urged the claims of the hospital upon the parish as renters."

In another parish a conditional resolution was adopted to give up unclaimed bodies, upon hearing of which, "Mr. Harrison offered to receive into the hospital, not only the sick paupers, without the usual compensation, but likewise their incurables, on condition that all their unclaimed bodies should be sent to Guy's. This offer was accepted, and a minute to that effect was made in the parish book, which, however, was rescinded at the next meeting, in consequence of the very intelligent surgeon exposing the affair in its proper light in many other parishes. I believe Mr. Harrison has made similar offers elsewhere."

Here is a pretty catalogue of compacts and treaties bctween high contracting parties, - all of them, doubtless, we may be told, originating in a love of science, and conducted in a spirit of true philanthropy. These are the "exertions amongst the parishes" which the witer in the nifuing Post deems so worthy of his commendation. These are the things which men lo, when, to borrow again the " ords of the Port, "men have a motive for their txi tions."

liere, Mr. Editor, let me pause, and look back unon what i have written. I find that 1 have trespassed already too far 
upon your valuable space, and yet $I$ have not half done. Will you then allow me to resume the subject next week ? I have not told you what the men of King's College have done,- what the University people have done-what those at St. George's have done. When all this is laid betore you, you will have an essay on " body-snatching;"you will see at once its cause and its cure and who will say that it should not be put an end to in whatever form it rises up? The practice of exhumation has been suppressed by law. Shall the spirit of bodysnatching be permitted to walk ahroad amongst us disguised in the garb of a gentleman?

November 19 th, 1834 .

$$
\text { I am, Sir, yours, \&c. }
$$

Jones Quain.

50, Great Coram-street, Russell-square.

\section{THE NEW COLLEGE REGULATIONS.}

To the Editor of The Laxcet.-Sir,--. Whatever diversity of impression may exist in the medical school of the London University on immaterial points respecting the late meeting of students in their anatomical theatre, please to let this be distinctly understood, if you notice that meeting in your Journal, - that seniors and juniors, - one and all in the surgical classes of those who think and speak for themselves, and these amount to nearly 250 in number-consider the new regulations issued by the College of Surgeons, umnecessary and vexatious, and such as ought neither to have been imposed upon gentlemen, nor put forth by functionaries whose sole desire is to promote science, and guarantee to the public a competent supply of surgeons. If the Council really want to secure the competency of such candidates as are induced to present themselves at the College, why do they not institute the true test of knowledge, - a public examination,- - granting the diploma according as the candidate proves by his answers that he understands and can practise the art of surgery? Every student knows that registrations and certificates are no evidence of attainments or ability, and as for the trumpery private "examination" which is instituted by the Board of Examiners after the purchase of eertificates from the examiners and their friends in other places, it is (according to the report of every student that I have ever known to pass) a scandal to the age. God help the public which has to trust to that test of competency! But the certificate-system must be too profitable to the Council to be abandoned. Such, at least, is the deduction derived during the various payments made for securing the required certificates by your obedient humble servant,

A Senior Student of the St. Pancras, Nov. 18th. UNIVERSITY.

Revival of the Donngs in Conduit Street. - To the Editor of The LaxCET. - Sir, - The respect I have always had for the medical profession, and a sense of the benefits it confers on mankind, induce me to advert, through the medium of your inestimable Journal, to a system of practice which merits reproach, and that too in the establishment of an individual from whom we have a right to expect very different conduct.

Severely afflicted with a disease in the urethra, I was recommended to consult Sir Astley Cooper. On calling at his house, his servant told me that he was in France, but that his partner would see me. Before having time to reflect, a person introduced himself to me, who endeavoured most clumsily and ineffectually to pass a bougie, when $I$ insisted that the attempt should no longer be persevered in unless I could see Sir Astley Cooper himself. I then prepared to go, but when on the point of leaving the room he said," I suppose, Sir, you know our terms. Our terms are a guinea!" I did not, howerer, submit to such an imposition, and I have sincederived satisfaction from not submitting to the attempt at extortion, having found out that this partner or representative of the great Sir Astley is no less a man than the son of his former footman. I have the honour to remain, Sir, your obedient servant, J. M.

P.S. I am told that Sir Astley receives two-thirds of the fees which his 'partner' succeeds in obtaining.

Senex to the Editor of The Lancer. - Sir, Having been a reader of your Jour. nal for nine years,-having, 1 may say, with a jealons eye, scrupulously watched your conduct,- having, in almost every act of your public conduct, had reason to applaud it,-I have really never felt more annoyed, or more hurt, than on perusing the farrago of sycophantic nonsense which was alleged to be the "dedication" written by Dr. Hope in his work on the Heart. It is necessary, Sir, sometimes, to be serious even while we are jesting. Such an imputation on the character of $\mathrm{Dr}$. Hope, if it were to remain uncontradicted, might 